Tatiana Czerska

Uniwersytet Szczeciński

\title{
Post-koiné, czyli Anity Jarzyny projekt krytyki nieantropocentrycznej
}

Jarzyna Anita (2019), Post-koiné. Studia o nieantropocentrycznych językach (poetyckich), Wydawnictwo Uniwersytetu Łódzkiego. Łódź.

Refleksja nad podmiotowością bytów innych niż człowiek, kwestionująca dotychczasową hierarchię stworzeń staje się w ostatnich latach jednym $\mathrm{z}$ najważniejszych nurtów w naukach humanistycznych. Praca Anity Jarzyny Post-koiné. Studia o nieantropocentrycznych językach (poetyckich), opublikowana przez Wydawnictwo Uniwersytetu Łódzkiego w 2019 roku, stanowi zwieńczenie wieloletnich badań autorki, szczególnie w ramach studiów nad Zagładą i animals studies. Łódzka badaczka podejmuje wezwanie Ewy Domańskiej do przeorientowania humanistyki i stworzenia projektu humanistyki ekologicznej czy też nieantropocentrycznej:

Jednym z największych wyzwań, przed którym stoją dziś badacze jest de-antropocentryzacja humanistyki. Nie chodzi rzecz jasna o wyrugowanie człowieka z badań, lecz raczej o odejście od humanistycznej wizji człowieka jako miary wszechrzeczy i centrum zainteresowań badawczych i stworzenie projektu humanistyki nie-antropocentrycznej (Domańska 2008: 11). 
Głównym założeniem tak pojętej humanistyki jest porzucenie wizji człowieka jako najważniejszego elementu rzeczywistości i głównego obiektu zainteresowań badawczych na rzecz podejścia nieantropocentrycznego.

Prezentowana publikacja wyrasta z przekonania, że należy ponownie przyjrzeć się językom poetyckim, poszukując świadectw dekonstrukcji retorycznego aparatu przemocy i wykluczenia zwierząt zapisanych w literaturze polskiej xx i Xxi wieku. Autorka poezję wyróżnia jako dziedzinę podejmującą krytyczną refleksję nad antropocentrycznie ufundowaną koiné, czyli językiem „wspólnoty określającej się wobec barbarzyńców (a może nawet przeciw barbarzyńcom) i ich niezrozumiałej mowy, sprawiającej wrażenie bełkotu, nieartykułowanych, nieledwie zwierzęcych dźwięków” (Jarzyna 2019: 42). Odwołując się do tradycji hermeneutyki, bazując też na pracy U-chodzić Tadeusza Sławka, proponuje zastąpić koiné nowym rodzajem kodu, który znosi hierarchię gatunków z człowiekiem w centrum, czyli post-koiné:

Post-koiné stara się dosięgnąć bezmownej (i często nienazwanej) reszty, niekoniecznie nawiązać przy tym trwałą więź czy porozumienie, przede wszystkim nie wyróżniać ludzkiej pozycji, ludzkiego podmiotu spośród innych gatunków. O ten język upomina się poezja - w swej istocie polifoniczna - która od razu zrzeka się dyktatorskich roszczeń, zawsze obejmuje wiele idiomów, wiele wyobraźni niedających się ujednolicić, sprowadzić do jednej perspektywy (Jarzyna 2019: 42).

Z perspektywy posthumanistycznej krytyki antropocentryzmu podejmuje Jarzyna rozważania dotyczące sposobów autonomizowania zwierząt w poezji i nie tylko. Zadaje pytanie o charakter poetyckiej metarefleksji na temat możliwości nieantropocentrycznego mówienia o zwierzętach. Nadrzędne zadanie, jakie sobie stawia autorka monografii, polega na „zrekonstruowaniu wielowątkowej narracji o krytycznym języku relacji ze zwierzętami wyłaniającej się z poezji polskiej drugiej połowy xx wieku i początku xxI wieku” (Jarzyna 2019: 43). Badaczka twierdzi bowiem, że dyskurs posthumanistyczny potrzebuje szerszej, międzygatunkowej, niestabilnej formuły post-koiné, obejmującej języki polemiczne względem dotychczasowego, zbyt wąskiego modelu wspólnoty. Post-koiné to w omawianej pracy język wystrzegający się przekonania o własnej omnipotencji, świadomy zagrożeń wynikających z podobnych aspiracji. Poezja upomina się o alternatywne języki - inkluzywne, wyczulone na kody wymierzonej w zwierzęta przemocy. Jarzyna nie odrzuca przy tym antropomorfizacji, ale zaznacza, że musi być ona pojmowana w sposób krytyczny, 
niepodporządkowana ludzkiej ekspresji, musi wynikać z potrzeby poznania i głębszego zrozumienia zwierząt.

W rozdziałach wstępnych badaczka w systematyczny sposób prezentuje prężnie rozwijający się od lat sześćdziesiątych xx wieku nurt badań ekokrytycznych. Jak sama przyznaje, czerpie inspiracje głównie z eseju Sławka U-chodzić, proponującego rozumienie podmiotowości otwartej na to, co pozaludzkie. W Post-koiné... obszernie prezentowane są także inne formułowane przez polskich badaczy postantropocentryczne projekty interpretacyjne: Aleksandra Nawareckiego (który jako pierwszy w polskim literaturoznawstwie wystąpił z koncepcją zoofilologii), Anny Barcz (autorki koncepcji realizmu ekologicznego), Anny Filipowicz (proponującej postantropocentryczne odczytanie kanonicznych dzieł poetyckich), Piotra Krupińskiego (autora pionierskiej na polskim gruncie pracy poświęconej zwierzętom i Zagładzie). Jarzyna polemizuje z wymienionymi autorami, wskazując pojęciowe niedostatki dyskursu literaturoznawczych studiów nad zwierzętami. W odniesieniu do książki Filipowicz (Prze)zwierzęcenia poetyckie drogi do postantropocentryzmu przyznaje, że jej autorka także poszukuje zapisywanej w wierszach alternatywnej wizji relacji międzygatunkowych, kierując się kryterium emancypacji zwierzęcego podmiotu. Omawiana tu propozycja jest jednak wobec propozycji gdańskiej badaczki tyleż komplementarna, co niezależna. Jarzynę interesuje rola poezji w procesie dekonstruowania języka hegemonii antropocentrycznej oraz charakter poetyckiej metarefleksji dotyczącej nieantropocentrycznego mówienia o zwierzętach. W swoim projekcie podąża za ustaleniami światowych przedstawicieli humanistyki nieantropocentrycznej (Cary'ego Wolfe'a, zoologa Donalda Griffina oraz filozofek Eriki Fudge, Mary Midgley czy Barbary Noske). Przywołuje różnorakie stanowiska wypracowane w ramach studiów nad zwierzętami (m.in. Érica Barataya, Rosi Braidotti, Elisabeth de Fontenay, Donny Haraway, Kari Weil). $\mathrm{W}$ ten sposób, konfrontując się z badaniami światowymi, wypracowuje własny, oryginalny idiom badawczy. Trzeba podkreślić, że żadnego z wymienionych ujęć nie traktuje łódzka badaczka jako interpretacyjnie uprzywilejowanego.

W przeciwieństwie do wielu rozbudowanych projektów humanistycznych ten bierze początek w literaturze. Praca ma charakter monografii kontekstowej (to określenie samej autorki), na którą składa się analiza szerokiego spektrum przypadków. Ich wybór zadecydował o układzie pracy, wyznaczył podział na cztery części problemowe, składające się z osiemnastu rozdziałów. Wśród analizowanych w książce autorów znaleźli się twórcy reprezentujący różne pokolenia i różne dykcje (m.in. Krystyna Miłobędzka, Tadeusz Nowak, Nelly Sachs, Jerzy Ficowski, Ryszard Krynicki, Justyna Bargielska czy Michał Książek). 
Jak się okazuje, kwestia podmiotowości bytów innych niż człowiek interesuje poetów różnych generacji. Niekwestionowaną zaletą publikacji jest wybór takich autorów, których wrażliwość nie została do tej pory w ogóle określona jako postantropocentryczna, oraz takich, w których twórczości świadectwa wyczulenia na los zwierząt i roślin pojawiały się incydentalnie. Ich dobór może jednak nasuwać wątpliwości, zastanawia nieobecność tekstów wydających się oczywistymi w tym kontekście (np. Zagłady gatunków Wiktora Woroszylskiego), a niektórym czytelniczkom i czytelnikom może brakować gruntowniejszego uzasadnienia dokonanego wyboru twórców i dzieł.

Mimo że kolejne rozdziały stanowią zamkniętą całość, a wybrane do analizy wiersze cechują różne poetyki, Jarzyna tworzy z nich interesujące konstelacje. W pierwszej części pracy, zatytułowanej Innymi słowy, autorka prezentuje swoją koncepcję post-koiné, odróżniając ją od innych, wyrosłych na polskim gruncie, postantropocentrycznych projektów interpretacyjnych. W kolejnych częściach książki łódzka badaczka, dodajmy - redaktorka pisma „Narracje o Zagładzie”, ukazuje paralelę między dyskursem o Zagładzie a wcześniejszymi lub równoległymi literackimi konfrontacjami świata ludzkiego ze zwierzęcym. Opisując Holokaust w kontekście relacji ludzko-zwierzęcych, formułuje pytanie, na ile stać się one mogą katalizatorem nieantropocentrycznej wyobraźni poetyckiej.

Warto zwrócić uwagę na rozdział traktujący o literaturze dziecięcej - Dzieci i ryby (wiersze na glosy). Uświadamia on potrzebę kształcenia nowej wrażliwości i otwierania młodego odbiorcy na kwestie związane z tworzeniem od podstaw relacji człowieka i natury. Na przykładzie wierszy Jacka Podsiadły i Dariusza Suski autorka pokazuje powszechnie aprobowany, wpisany w proces socjalizacji mechanizm formatowania relacji dzieci ze zwierzętami, często utrwalany w wierszach adresowanych dla najmłodszych, obalany jednak w poezji uchodzącej za kierowaną do dorosłych. Podejmując te kwestie, Jarzyna nawiązuje do children studies, które chętnie posługują się analogią podmiotu dziecięcego i podmiotu zwierzęcego. Osobny rozdział Szlemiele. Zwierzęta wobec Zagłady w literaturze dla dzieci, którego tytuł jest parafrazą tytułu książki Ryszarda Marka Grońskiego, poświęcony został literaturze dla dzieci opowiadającej o losach zwierząt w czasie wojny. Przywołane teksty, m.in. wspomniany Szlemiel Ryszarda Marka Grońskiego, Kotka Brygidy Joanny Rudniańskiej, Mój pies Lala Romana Kenta, Wojna na Pięknym Brzegu Andrzeja Marka Grabowskiego pozwalają spojrzeć na Zagładę z nieantropocentrycznej perspektywy. Zdaniem badaczki autorki i autorzy literatury dla dzieci zwracają uwagę na opresję antropocentrycznego języka i dyskryminację nie-ludzi, co widać na przykładzie tytułowego psa Szlemiela nazywanego „psem żydowskim” czy „osobnikiem niższej rasy”. 
Druga część monografii (Stan wyjątkowy, staus quo) jest poświęcona różnorakim ujęciom animalno-zagładowego imaginarium. Los Ormian i masakra stambulskich bezdomnych psów, myślistwo w III Rzeszy i Judenjagd, los zwierząt w hodowlach przemysłowych i Holokaust, rzeźnia i obozy Zagłady, mowa zwierząt i język dzieci to paralele, wokół których buduje Jarzyna swój projekt krytyki nieantropocentrycznej. Na refleksję na temat wciąż uchodzącego za kontrowersyjne porównania przemysłowej hodowli bydła do obozów zagłady naprowadza badaczkę interpretowany w osobnym rozdziale wczesny wiersz Nelly Sachs przełożony przez Ryszarda Krynickiego [Także tobie, o mój ukochany...]. Jarzyna dostrzega w tym utworze rozszerzenie wskazanych wyżej analogii o afirmatywne obrazy wspólnych człowiekowi i innym ssakom potrzeb bliskości.

W Post-koiné... pada też pytanie o udział religii w utrwalaniu schematów naszego stosunku do bytów innych niż ludzkie. Autorka odnajduje w powojennej liryce i sztuce polskiej przykłady teologicznych i etycznych polemik prowadzonych z myślą chrześcijańską, w których widać pragnienie wyjścia poza antropocentryzm w wymiarze życia duchowego. Ten fragment książki dotyczy przejawów opresji, obecnych w dyskryminujących, zdaniem badaczki, zwierzęta wytycznych Katechizmu Kościoła Katolickiego. Analizowane w tym miejscu wiersze Nowaka odczytane zostają w kontekście teologicznych refleksji Jerzego Nowosielskiego jako heretyckie w stosunku do religii katolickiej.

W części trzeciej (zatytułowanej Obyczaje) pojawia się katalog przemocowych praktyk wobec zwierząt - wpisanych w kulturę, obyczaje, więc społecznie aprobowanych i legitymizowanych w języku (zwłaszcza w inwektywach i eufemizmach), a demaskowanych w analizowanych w pracy wierszach. Jednym z ciekawszych zagadnień są rozważania leksykograficzne prowadzone m.in. w rozdziałach poświęconych masakrze stambulskich psów. Autorka zauważa, że we współczesnych słownikach języka polskiego wyrazy „rzeź” i „masakra” występują jako synonimy:

W objaśnieniach obu akcentuje się, że „rzeź” (ale rozumiana przenośnie) i „masakra” odnoszą się do aktów szczególnie brutalnych, bestialskich, zadawanych bez miłosierdzia. Ciekawe (i znamienne), że to nacechowanie „rzezi” znika w jej podstawowym znaczeniu, gdy dotyczy zwierząt (choć w tym kontekście „rzeź” zastępowana jest przez „ubój”, a neutralna będzie raczej pochodna - „rzeźnia”), ciekawe również, że już XIX-wieczne dykcjonariusze notują oba znaczenia słowa (Jarzyna 2019: 128). 
Zdaniem łódzkiej badaczki marginalne miejsce, jakie zajmuje masakra stambulskich psów w historiografii i tekstach kultury, dowodzi, że „w opowiadaniu o masowym zabijaniu zwierząt jesteśmy jeszcze mniej zaawansowani niż w opowiadaniu o ludobójstwach, dlatego budowanie tego rodzaju porównań okazuje się nie tylko uzasadnione, ale i funkcjonalne” (Jarzyna 2019: 132). Co więcej, w odczuciu autorki termin „ludobójstwo” okazuje się zbyt wąski, nie obejmuje bowiem mordu popełnionego na stambulskich psach i wszystkich innych masowych rzezi zwierząt, jakie miały miejsce w historii. W podobny sposób badaczka prowadzi refleksję wokół języka łowieckiego w rozdziale poświęconym analizie bliźniaczych formuł „Judenjagd” i „polowanie na Żydów”, występujących zarówno w pracach historiograficznych, relacjach ocalałych, jak i w wierszach. Obnaża tym samym eufemistyczny charakter słownictwa myśliwskiego mający ukryć prawdziwy, okrutny charakter polowań: „określenia «Judenjagd» oraz «polowanie na Żydów» dlatego, że powszechnie uznaje się je za deprecjonujące, podtrzymują antropocentryczną hierarchię" (Jarzyna 2019: 189).

W rozdziale Pomiotki, poświęconym tematyce macierzyństwa w poezji Justyny Bargielskiej i Joanny Mueller, Jarzyna dokonuje zestawienia matek ludzkich i zwierzęcych, wykazując patriarchalny wymiar języka, w którym kobiety i matki traktowane są animalistycznie i abiektalnie. W rozdziale Łajka na dobranoc autorka przybliża mniej znane w Polsce anglojęzyczne narracje (propagandowe, historiograficzne, kulturowe) poświęcone wykorzystywaniu zwierząt w programach lotów w kosmos. Reakcje na wysłanie w kosmos suczki Łajki, z góry skazanej na śmierć, badaczka odnajduje w wierszach Zbigniewa Herberta i Adama Włodka. Dociera też do innych utworów poświęconych suczce. Analizując z kolei wiersz Jerzego Kronholda Płacz, zestawia go z raportami na temat warunków panujących na fermach zwierząt futerkowych oraz z regulacjami prawnymi dotyczącymi tego typu hodowli: „Przedśmiertne głosy krów i lisów (oraz wszystkich innych gatunków wykorzystywanych przez człowieka), rozlegają się poza prawem, ale są wyrokiem” (Jarzyna 2019: 402).

Czwarta część (Wspólny świat: od-nowa) dotyczy namysłu nad konwencjami opisów przyrody, w szczególności obserwacji ornitologicznych (fachowych opracowań i atlasów), oraz nad możliwościami przeformułowania ich w taki sposób, by nie skutkowały uprzedmiotowianiem ptaków, ale też nie naruszały koniecznego dystansu istniejącego zwykle między nimi a ludźmi. W tej części pracy omawiane są także poetyckie narracje o międzygatunkowych relacjach opartych na wzajemnej bliskości (w rozdziale Gatunki rozkoszy). Autorka szuka w poezji świadectw budowania porozumienia między człowiekiem a zwierzęciem. Ostatnie studium poświęcone jest wierszowi Piotra Sommera Kolega z boiska, w którym badaczka dostrzega - wykraczającą poza zwyczajowy 
schemat - relację człowieka i psa, polegającą na wymianie ludzkiej opieki za bezgraniczne przywiązanie czy oddanie. Dochodzi do wniosku, że interakcje te mogą być znacznie bardziej skomplikowane, przybierając na przykład charakter wyłącznie koleżeński, a nawet partnerski.

Monografia Post-koine. Studia o nieantropocentrycznych językach (poetyckich) niewątpliwie stanowić będzie ważny punkt odniesienia dla powstających w przyszłości kolejnych studiów zogniskowanych wokół kluczowych problemów relacji człowieka i zwierzęcia widzianych w perspektywie posthumanistyki. Wysoka wartość prezentowanej książki wynika z przyjętej przez Jarzynę metodologii i z oryginalności interpretacji. Poetyckie opowieści zwierząt i o zwierzętach są odczytywane jako krytyka wielu dyskursów: antysemickiego, teologicznego, łowieckiego, patriarchalnego, rzeźnickiego, medycznego, zoologicznego. Nowatorstwo monografii wynika bowiem z wyszukiwania dla poetyckich narracji kontekstów spoza literatury. Autorka Post-koiné... jawi się nie tylko jako literaturoznawczyni, ale też antropolożka i historyczka. Gdy pisze o dziejach myślistwa w III Rzeszy lub o masakrze stambulskich psów w kontekście rzezi Ormian, jej odczytywanie literatury staje się elementem szerszego spojrzenia na problem relacji animalno-ludzkich. Problemy nurtujące badaczkę sytuują się w polu wrażliwości międzygatunkowej, której podstawę stanowią zbliżone nawyki i identyczne predyspozycje ludzi i zwierząt do odczuwania emocji. Szukając nowej formuły języka zdolnego opisać pomijane dotąd przypadki ludzko-zwierzęcych relacji, autorka pozostaje wierna mikrologii literackiej, co gwarantuje zachowanie równowagi między teoretycznymi rozważaniami a niezbędną w tego rodzaju rozprawie wrażliwością.

Książka Jarzyny proponuje oryginalną lekturę poetyckich i niepoetyckich utworów wrażliwych na zagadnienia $\mathrm{z}$ obszaru animals studies. Trzeba podkreślić, że mamy do czynienia z pionierską na gruncie polskim publikacją ze względu na próbę wypełnienia „białych plam” w recepcji ekologicznej twórczości nie tylko kanonicznych poetek i poetów xx i xx wieku. Jej autorka analizuje zarówno teksty nieznane, przybliżając je polskim odbiorcom, jak i te znane, proponując ich reinterpretacje. Wprowadza nową i istotną perspektywę w badaniach nad dwudziestowieczną literaturą polską. Intelektualna uważność, dostrzeganie luk w literaturoznawczej bibliotece oraz umiejętność prowadzenia dialogu $\mathrm{z}$ innymi tekstami polskich autorów poświęconymi studiom nad zwierzętami pozwalają uznać omawianą pracę za niezwykle wartościową propozycję badawczą, aczkolwiek czytelnikowi nie jest łatwo podążać tropem myślenia autorki ze względu na meandryczny, rozgałęziony (jakby biegnący równolegle w kilku kierunkach) charakter wywodu, liczne dygresje i przywoływania szeregu źródeł. 
Wart zaakcentowania jest sam sposób pisania Jarzyny, który nie jest bezstronny. Książka angażuje emocjonalnie czytelnika, sprawia, że nie może on pozostawać obojętnym wobec poruszanych tu kwestii. Wybrane przez badaczkę metodologie oraz krytyka stabilnych, antropocentrycznych wzorów będą wyzwaniem głównie dla przeciwników prowadzenia paralelnej narracji na temat losu ludzi i zwierząt. Projekt krytyki nieantropocentrycznej proponowany przez Jarzynę postuluje aktywizm literaturoznawczej refleksji, potrzebę jej zaangażowania w życie społeczne, zdolność do kształtowania myślenia i przekraczania utartych schematów. Postawa łódzkiej badaczki charakteryzuje się nie tylko empatią oraz odpowiedzialnością, ale także nieufnością w stosunku do ustalonych hierarchii i porządków oraz namysłem nad pomijanymi dotąd zagadnieniami.

Ze względu na szeroki kontekst książka Jarzyny może okazać się interesująca nie tylko dla literaturoznawców, co należy podkreślić jako niekwestionowany walor prezentowanej publikacji. Zmusza każdego czytelnika do przemyślenia własnego stosunku do istot innych niż ludzie. W Post-koiné... spotkanie ludzkiego i zwierzęcego jest wyrazem wiary w możliwość zaprowadzenia nowego porządku także poza przestrzenią akademii. A autorka potrafi umiejętnie połączyć fachowość i skrupulatność analiz z popularyzowaniem nowatorskich koncepcji. Wskazując na różnorodność relacji człowiek - zwierzę, obecnych w literaturze, wyzwala zwierzęta ze schematów i określających je kategorii. Kategoria post-koiné otwiera nowe możliwości interpretacyjne, jest zaproszeniem do dalszych poszukiwań literackich przykładów wrażliwości międzygatunkowej. Niewiele jest na gruncie polskiego literaturoznawstwa teoretycznych propozycji systematyzujących narzędzia krytyki posthumanistycznej, a Post-koiné. Studia o nieantropocentrycznych językach (poetyckich) bez wątpienia wypełnia tę przestrzeń.

\section{| Bibliografia}

Barcz Anna (2016), Realizm ekologiczny. Od ekokrytyki do zookrytyki w literaturze polskiej, Wydawnictwo Naukowe "Śląsk”, Katowice.

Domańska Ewa (2008), Humanistyka nie-antropocentryczna a studia nad rzeczami, „Kultura Współczesna”, nr 3, s. 9-21.

Filipowicz Anna (2017), (Prze)zwierzęcenia. Poetyckie drogi do postantropocentry$z m u$, Wydawnictwo Uniwersytetu Gdańskiego, Gdańsk.

Jarzyna Anita (2019), Post-koiné. Studia o nieantropocentrycznych językach (poetyckich), Wydawnictwo Uniwersytetu Łódzkiego, Łódź. 
Krupiński Piotr (2016), „Dlaczego gęsi krzyczały?”. Zwierzęta i Zagłada w literaturze polskiej xx i XxI wieku, Wydawnictwo Instytutu Badań Literackich, Warszawa.

Nawarecki Aleksander (2014), Parafernalia. O rzeczach i marzeniach, Wydawnictwo Uniwersytetu Śląskiego, Katowice.

Sławek Tadeusz (2015), U-chodzić, Wydawnictwo Uniwersytetu Śląskiego, Katowice.

\section{| Abstrakt}

\section{Tatiana Czerska}

Post-koiné, czyli Anity Jarzyny projekt krytyki nieantropocentrycznej

Artykuł stanowi przegląd i omówienie monografii Anity Jarzyny Post-koiné. Studia o nieantropocentrycznych językach (poetyckich), która jest jedną z kluczowych rozpraw badających związki ludzko-zwierzęce na materiale poezji polskiej xx i xxı wieku. Książka Jarzyny jest nie tylko przykładem zręcznego aplikowania metodologii z pogranicza posthumanizmu i animal studies. Stanowi oryginalną i nowatorską propozycję nieantropocentrycznego czytania literatury, jest także ważnym głosem w debacie o budowaniu ładu ekologicznego i miejscu oraz roli zwierząt w życiu człowieka.

Słowa kluczowe: poezja; język; animal studies; ekokrytyka; posthumanizm; humanistyka nieantropocentryczna

\section{| Abstract \\ Tatiana Czerska \\ Post-koiné, or Anita Jarzyna's Project of Non-anthropocentric Criticism}

The article below is an overview and discussion of Anita Jarzyna Post-koinés monograph. Studies on non-anthropocentric (poetic) languages, which is one of the key treatises examining human-animal relationships on the material of Polish poetry of the 2oth and 21st centuries. Jarzyna's book is not only an example of skilful application of methodologies from the border of posthumanism and animal studies. It is an original and innovative proposition of a non-anthropocentric reading 
of literature. It is also an important voice in the debate on building an ecological order and the place and role of animals in human life.

Keywords: poetry; language; animal studies; ecocriticism; posthumanism; non-anthropocentric humanities

\section{| Nota o autorze}

Tatiana Czerska - dr hab., prof. us, literaturoznawczyni, pracuje w Instytucie Literatury i Nowych Mediów (Wydział Humanistyczny, Uniwersytet Szczeciński). Zainteresowania naukowe: autobiografizm, diarystyka, epistolografia, tożsamość kulturowa, literatura pogranicza. Najważniejsze publikacje: W. Woroszylski, Z. Żakiewicz „Losy nosza nas różnymi drogami”. Listy 1969-1996 (oprac., Warszawa 2020), Diarystki. Tekst i egzystencja (Szczecin 2018), Przerabianie Żeromskiego (red., Wrocław 2016), Autobiografie (po)graniczne (współred. z I. Iwasiów, Kraków 2016), Między autobiografia a opowieścia rodzinna. Kobiece narracje osobiste $w$ Polsce po 1944 roku w perspektywie historyczno-kulturowej (Szczecin 2011), Od małej ojczyzny do Uniwersum. Sacrum w twórczości Zbigniewa Żakiewicza (Szczecin 2006). Prezeska szczecińskiego oddziału Towarzystwa Literackiego im. Adama Mickiewicza.

E-mail: tatiana.czerska@usz.edu.pl

ORCID 0OOO-0OO2-3752-5498 